\begin{tabular}{|c|l|}
\hline Title & $\begin{array}{l}\text { Comparison of potentially toxic metals leaching from weathered rocks at a closed mine site between laboratory columns } \\
\text { and field observation }\end{array}$ \\
\hline Author(s) & Villafane, Omar R. Salinas; Igarashi, Toshifumi; Kurosawa, Mitsuru; Takase, Toshio \\
\hline Citation & $\begin{array}{l}\text { A pplied Geochemistry, 27(12), 2271-2279 } \\
\text { https://doi.org/10.1016/.apgeochem.2012.08.013 }\end{array}$ \\
\hline Issue Date & 2012-12 \\
\hline Doc URL & http://hdl.handle.net/2115/50932 \\
\hline Type & article (author version) \\
\hline File Information & AG27-12_2271-2279.pdf \\
\hline
\end{tabular}

Instructions for use 


\title{
Comparison of potentially toxic metals leaching from weathered rocks at a closed mine site between laboratory columns and field observation
}

Omar R. Salinas Villafane ${ }^{1}{ }^{*}$, Toshifumi Igarashi ${ }^{1}$, Mitsuru Kurosawa ${ }^{2}$ and Toshio Takase ${ }^{2}$

${ }^{1}$ Laboratory of Groundwater and Mass Transport, Graduate School of Engineering, Hokkaido University, Sapporo, 060-8628, JAPAN

${ }^{2}$ Mitsubishi Materials Corporation, Saitama 330-8508, JAPAN

*Corresponding author, E-mail: omar@trans-er.eng.hokudai.ac.jp; Fax.: +81-117066309; Tel.:

+81-117066311

Editorial handling by L. Munk

\begin{abstract}
Potentially toxic metals, such as $\mathrm{Cu}, \mathrm{Pb}$ and $\mathrm{Zn}$, are leached from weathered rocks at many closed mine sites due to the acidic environments and mineralogical modifications. The mobilized toxic metals may cause contamination of surrounding water bodies. In this study, both laboratory column experiments and field observations at a former mine located in the north of Japan were carried out to compare the leaching behavior of $\mathrm{Cu}, \mathrm{Pb}$ and $\mathrm{Zn}$. The thickness of the surface weathered rock was varied (10, 20 and 30 $\mathrm{cm})$ for the columns experiments while porous cups for porewater sampling were set up at different depths ( GL-15, -45, -70, and $-95 \mathrm{~cm}$ ) for the field observations. Deionized water was added once a week over 75 weeks to the columns to simulate rainfall while porewater was extracted by a vacuum pump in several sampling campaigns (over 18 months). Similar low $\mathrm{pH}$ and leaching behavior of potentially toxic metals were observed for column experiments and field observations. A moderate increase in concentration with depth was observed for $\mathrm{Cu}$ and $\mathrm{Zn}$. However, no increase in concentration was observed for $\mathrm{Pb}$. This suggests that the leaching of $\mathrm{Cu}$ and $\mathrm{Zn}$ is enhanced by the length of the flow pathway through the weathered rock layer while $\mathrm{Pb}$ concentration is restricted by the precipitation of insoluble $\mathrm{Pb}$ sulfate. Thus, the thickness of the weathered rock layer is an important parameter that should be taken into consideration to estimate the loads of some potentially toxic metals, which is important when designing remediation schemes.
\end{abstract}

\section{Introduction}

Contamination of water bodies and soils due to mining activities has been of great concern over the last decades (Azapagic, 2004). Present day and historic mining and processing activities have resulted in the discharge of large quantities of tailings to river systems (Miller, 1997; Hudson-Edwards et al., 2003). Several researchers have reported pollution of soils and water bodies, due to the formation of acid rock drainage (ARD), all over the world (Sahu et al., 1994; Jung and Thornton, 1997; Miller et al., 2004; Bech et al., 2012), although the true scale of the environmental contamination caused by the activities is difficult to assess accurately (Johnson and Hallberg, 2005). Every mine is distinctive in its soil pollution and ARD potential; thus, the nature and size of the associated risk and feasibility of mitigation options will vary from site to site (Akcil and Koldas, 2006).

After mine closure, surface rocks and tailings are exposed to weathering unless they are properly covered and/or remediated. This weathering can change the chemical and physical properties of the rocks over long periods of time. Thus, transformation in the mineralogy on the site may increase the amounts of easily-mobile toxic trace metals (Ramos Arroyo and Siebe, 2007) by altering the original parent sulfide minerals into secondary minerals such as carbonates and oxides. From field observations, metal mobility has been shown to depend on the $\mathrm{pH}$ of the tailings porewater (Dubrovsky et al., 1985).

To estimate the quantities of potentially toxic metal release, several studies have been conducted using different approaches, such as columns experiments (Kossoff et al., 2011) and field observations (Azcue et al., 1995). However, few have been conducted using a direct comparison of both approaches, although 
understanding the potentially toxic metal release into the water is crucial in the prediction, prevention and remediation of environmental impacts (Jurjovec et al., 2002).

In this context, the present study is concerned with the release of potentially toxic metals in weathered rocks collected at an abandoned mine site in the north of Japan. The objective is to compare the leaching of $\mathrm{Cu}, \mathrm{Pb}$ and $\mathrm{Zn}$ from weathered rock between column experiments with different bedrock depths and field observations, and then to evaluate their mobility and the geochemical evolution of the weathered rock porewater at the field site in contrast with the controlled conditions of the laboratory column experiments. Addition of water to the columns was done weekly to simulate expected rainfall and the effluent collected. At the mine site seasonal sampling was conducted using porous cups set at different depths. In addition, potential solubility-control phases of the metals were evaluated using geochemical calculations.

\section{Materials and methods}

\subsection{Site description and characterization of rock samples}

The study area, known as Komaki mine, is a former underground mine located in Kazuno city, NE Akita prefecture, Japan. The geology of the closed mine site consists of the tertiary green tuff / tuff breccia and rhyolite, in which a Kuroko style ore body and iron sulfide dissemination zones in the strata were excavated to produce $\mathrm{Au}, \mathrm{Ag}, \mathrm{Cu}, \mathrm{Pb}$ and $\mathrm{Zn}$. The mine was in operation from 1880 to 1978, and since its closure in 1978 a water treatment plant has been operated to neutralize the ARD from drifts, shafts and tailings dams. The total flow rate, which is a collection of all water bodies including seepage from drifts, shafts and tailings dams originates from the mountain where the mine was located, is approximately 0.6 $\mathrm{m}^{3} / \mathrm{min}$, and the raw water has a $\mathrm{pH}$ of 2.8 with high contents of potentially toxic metals. There is a lack of surface vegetation due to the acidic environment.

Three weathered rocks samples and one fresh rock sample (obtained from a recent cut of a rock formation at the site) were collected from the ground surface at different locations on the site (Fig.) 1. About $5 \mathrm{~kg}$ of rock were collected randomly from areas of approximately $5 \mathrm{~m} \mathrm{x} 5 \mathrm{~m}$ using a hand shovel. The samples were dried, crushed using a jaw crusher or an agate mortar, mixed completely, and then sieved using a $5 \mathrm{~mm}$ aperture screen. The crushed rock samples were subjected to batch leach experiments and the leachates analyzed. Twenty grams of the crushed rock sample and $200 \mathrm{~mL}$ of deionized water were placed in a $250 \mathrm{~mL}$ Erlenmeyer flask, and stirred at $120 \mathrm{rpm}$ for $24 \mathrm{~h}$ at $16 \pm 1^{\circ} \mathrm{C}$. The $\mathrm{pH}$, redox potential (ORP), and electrical conductivity (EC) of the leachate were measured using pH, ORP and EC meters, respectively. After the measurements, the leachate was filtered using $0.45 \mu \mathrm{m}$ Millipore sterile filters prior to chemical analysis. The weathered rocks characterized here were later used for column experiments.

For the chemical and mineralogical composition analyses, the coarsely crushed samples were ground. The chemical composition of the samples was quantified using an energy dispersive X-ray fluorescence spectrometer, (Xepos, Rigaku Corporation, Japan) while their mineralogical composition was determined using an X-ray diffractometer (Multiflex, Rigaku Corporation, Japan). Both analyses were conducted using pressed powders of the samples. The analysis for total $\mathrm{C}$ in the rocks was done by using a total organic carbon analyzer (TOC-L, Shimazu, Japan) coupled with a solid sample module (SSM-5000A, Shimazu, Japan).

\subsection{Laboratory column experiments}

Three PVC columns with an inner diameter of $52 \mathrm{~mm}$ and height of $400 \mathrm{~mm}$ were built. A cover with perforated holes was also designed in order to simulate rain as well as to act as a barrier against outside dust and contaminants. A schematic illustration is shown in Figure 2. The columns were packed with the weathered rock collected at sampling area $\mathrm{K}_{2}$. Column 1 was packed to a height of $100 \mathrm{~mm}$ with crushed and sieved rock sample (378 g), column 2 to a height of $200 \mathrm{~mm}(756 \mathrm{~g}$ ) and column 3 to height of 300 $\mathrm{mm}(1134 \mathrm{~g})$, respectively. No apparent stratification of the weathered rocks was observed after packing. 
The infiltration of rainfall was simulated by adding $60 \mathrm{~mL}$ of deionized water through the cover with perforated holes. This volume of water represents the amount of precipitation expected every two weeks at the mine site, obtained from historical climate data. Addition of water started simultaneously for all columns and was done once a week until week 75 . However, leacheate was first collected in column 1 after 2 weeks, column 2 after 3 weeks, and column 3 after 4 weeks. The leachates were collected 2 days after the water was added. Thus, the infiltration through an unsaturated layer was in unsteady state. The pH, ORP, temperature, and EC were measured immediately after collection, and the leachates were filtered before chemical analysis. The room temperature during the experimental period (November 2009 to April 2011) was $15 \pm 2{ }^{\circ} \mathrm{C}$. The variation in temperature does not have a significant effect in the leaching of potentially toxic metals as reported in a previous study (Salinas Villafane et al., 2012). Throughout the remainder of the paper, column 1 is referred to as case 1, column 2 as case 2, and column 3 as case 3 .

\subsection{Field observations}

Field observations were performed at the former mine site in order to compare the evolution of porewater with the leachate obtained from the column experiments with different rock bed thicknesses. For this, a flat surface area of $4 \mathrm{~m} \mathrm{x} 4 \mathrm{~m}$ was prepared at the mine site to carry out porewater sampling. A water sampling system using porous cups was set at different depths (GL -15, -45, -70, and -95 cm), as shown in Figure 3. Seven sampling campaigns were undertaken between November of 2009 and June of 2011. Sampling was done by using a vacuum pump adjusted to $-70 \mathrm{kPa}$ pressure to extract porewater into a 500 $\mathrm{mL}$ Erlenmeyer flask. The $\mathrm{pH}, \mathrm{ORP}, \mathrm{EC}$ and temperature were measured within a few hours of sampling, which was followed by filtration using $0.45 \mu \mathrm{m}$ Millipore sterile filters. The filtered samples were then sealed and taken for chemical analysis. The ORP results for all laboratory experiments and field observation were converted into Eh values by using the following equation:

$\mathrm{Eh}=\mathrm{ORP}+206-0.7(\mathrm{t}-25) \mathrm{mV}$

where, Eh denotes the ORP value measured using a standard hydrogen electrode as the reference electrode $(\mathrm{mV})$; ORP denotes the value measured with the $\mathrm{Ag} / \mathrm{AgCl}$ reference electrode $(\mathrm{mV})$, and the water temperature $\left({ }^{\circ} \mathrm{C}\right)$.

\subsection{Chemical Analysis}

Filtrates of batch suspensions, column leachates, and porewater were analyzed. An inductively coupled plasma atomic emission spectrometer (ICP-AES) (ICPE-9000, Shimadzu Corporation, Japan) was used for quantifying dissolved metal concentrations $>0.1 \mathrm{mg} / \mathrm{L}$ whereas the ICP-AES coupled with an ultrasonic aerosol generator that had a detection limit of 0.01 to $0.001 \mathrm{mg} / \mathrm{L}$ was used for quantifying dissolved metal concentrations $<0.1 \mathrm{mg} / \mathrm{L}$. The results of the analyses using ICP-AES had a margin of error of ca. 2 - 3\% while the ultrasonic aerosol generation process had an uncertainty of ca. 5\%. A cation chromatograph (Dionex ICS-90, USA) and an anion chromatograph (Dionex ICS-1000, USA) were used for measuring the concentrations of major cations $\left(\mathrm{Ca}^{2+}, \mathrm{K}^{+}, \mathrm{Na}^{+}\right.$, and $\left.\mathrm{Mg}^{+}\right)$and anions $\left(\mathrm{Cl}^{-}, \mathrm{NO}_{3}^{-}\right.$, and $\mathrm{SO}_{4}{ }^{2-}$ ), respectively. Both chromatographs had a margin of error of ca. $2-3 \%$.

\subsection{Partition coefficient calculations}

Partition coefficients $\left(\mathrm{K}_{\mathrm{d}}\right)$ can be used to infer the metal transported in groundwater and are defined as the relationship between metal partitioned in the solid and liquid phases of soil (Lee, 2006). The calculation of the $\mathrm{K}_{\mathrm{d}}$ value for potentially toxic metals was done by using the following equation:

$$
\mathrm{K}_{\mathrm{d}}=[\text { metal }]_{\text {solid phase }} /[\text { metal }]_{\text {liquid phase }}
$$

where, $\mathrm{K}_{\mathrm{d}}$ is the distribution coefficient $\left(\mathrm{L} \mathrm{kg}^{-1}\right)$; [metal] $]_{\text {solid phase }}$ is the metal content of the rock sample (mg $\left.\mathrm{kg}^{-1}\right)$; [metal $]_{\text {liquid phase }}$ is the metal content of the leachate of the batch experiments $\left(\mathrm{mg} \mathrm{L}^{-1}\right)$. 
Smaller $\mathrm{K}_{\mathrm{d}}$ values correspond to higher metal concentrations in soil solution and, therefore, that the metal is more available for transport in groundwater, porewater and/or other water body. The $\mathrm{K}_{\mathrm{d}}$ is not a constant value and may vary by several orders of magnitude (Camargo et al., 2007). Therefore, $\log \mathrm{K}_{\mathrm{d}}$ values are used in this paper.

\subsection{Geochemical evaluation}

Geochemical evaluation of analyzed samples was performed using PHREEQC (version 2.18.03) (Parkhurst and Appelo, 1999) to elucidate the speciation of dissolved constituents and the saturation states of minerals.

\section{Results}

\subsection{Characterization of weathered rock samples}

The chemical composition of the rock samples are shown in Table 1. The $\mathrm{S}$ content ranges from 0.48 to 1.0 wt. \%. On average, metal contents of the four rock samples were 52.3 (34-98) ppm for $\mathrm{Cu}, 15.8$ (10-23) $\mathrm{ppm}$ for $\mathrm{Pb}$ and 74.5 (31-95) $\mathrm{ppm}$ for $\mathrm{Zn}$. These concentrations are within soil and crustal abundances (20-50 ppm for $\mathrm{Cu}, 14-19 \mathrm{ppm}$ for $\mathrm{Pb}$ and 60-75 ppm for $\mathrm{Zn}$ ) (Sposito, 1989; Emsley, 2003). The minerals identified are listed in Table 2. Pyrite was detected in all samples irrespective of the degree of weathering. Some other secondary minerals, such as sericite, kaolinite, goethite and hematite, have been detected on the weathered surfaces of rocks collected at other sampling points at the site (Mitsubishi Materials, 2010). The organic C content of all 4 samples was found to be under the detection limit of the equipment used (100 ppm).

The chemical composition of solutions extracted from the rock samples are presented in Table 3 . The solutions are clearly acidic and the highest $\mathrm{pH}$ (4.52) was obtained for the fresh rock sample. The dissolved potentially toxic metal concentrations in the suspension are higher than the average concentrations reported by Kabata-Pendias and Pendias (2001) for uncontaminated soils, solutions from uncontaminated soils ranging from 0.5 to $135 \mu \mathrm{g} / \mathrm{L}$ for $\mathrm{Cu}, 0.6$ to $63 \mu \mathrm{g} / \mathrm{L}$ for $\mathrm{Pb}$, and 1 to $750 \mu \mathrm{g} / \mathrm{L}$ for $\mathrm{Zn}$. As also reported in a previous study, this acidic environment enhances the pollution of the water bodies (surface water and seepage) at the site, where $\mathrm{Cu}, \mathrm{Pb}$ and $\mathrm{Zn}$ concentrations were reported to be as high as 4.33, 0.28 and 2.16 $\mathrm{mg} / \mathrm{L}$, respectively (Salinas Villafane et al., 2009).

\subsection{Laboratory column experiments}

The change in $\mathrm{pH}$ of the column experiments is illustrated in Fig. 4a. The $\mathrm{pH}$ values in case 1 (3.20-3.58, median=3.35), 2 (3.13-3.44, median=3.26), and 3 (3.16-3.54, median=3.28) were all acidic throughout the experiments ( 75 weeks). Oxic conditions were observed throughout the experiments (Fig. $4 \mathrm{~b}$ ), with similar positive Eh values $(550-700 \mathrm{mV})$ for all cases, irrespective of the layer thickness. This condition is favorable to the oxidation of the residual pyrite. The highest values of EC were found in the first leachate in all cases $(0.448 \mathrm{mS} / \mathrm{cm}$ for case $1 ; 0.540 \mathrm{mS} / \mathrm{cm}$ for case 2 , and $0.675 \mathrm{mS} / \mathrm{cm}$ for case 3$)$ and decreased gradually with time as shown in Figure 4c. This implies that easily dissolved chemical species were released promptly after the addition of water. The EC values were higher in accordance with the thickness of the layer.

The concentration changes of potentially toxic metals and major ions are shown in Figure 5. As a general trend, concentrations of the major ions tend to be higher at the beginning of the experiments and then decrease as time elapses, as observed for $\mathrm{Ca}^{2+}, \mathrm{Mg}^{2+}, \mathrm{SO}_{4}{ }^{2-}$ and $\mathrm{Cl}^{-}$. Similar behavior was observed for $\mathrm{Cu}$ and $\mathrm{Zn}$. Case 3 on average had the highest concentrations of the cases, especially at the beginning of the experiments $(1.80 \mathrm{mg} / \mathrm{L}$ for $\mathrm{Cu} ; 7.83 \mathrm{mg} / \mathrm{L}$ for $\mathrm{Pb}$, and $2.37 \mathrm{mg} / \mathrm{L}$ for $\mathrm{Zn}$ ), followed by case 2 and 1 . However, $\mathrm{Fe}$ and $\mathrm{Pb}$ did not follow this trend. Iron leaching remained low throughout the experiments for all cases being in the range of $0-2 \mathrm{mg} / \mathrm{L}$, except for weeks 34 to 49 in case 3 , where concentrations were 
as high as $5 \mathrm{mg} / \mathrm{L}$. Lead leaching showed a slight increase with time for the three cases although a considerable increase was observed in case 3 for weeks 34 to 49 similar to Fe. This is attributed to the dissolution of some secondary Fe-bearing minerals, such as hydroxides, which also contributes to the release of $\mathrm{Pb}$ that is co-precipitated and/or adsorbed on these phases.

\subsection{Porewater sampling}

The chemical characterization of porewater at the mine site was done to elucidate its evolution with depth. Table 4 shows the results for $\mathrm{pH}$, ORP and EC with respect to depth. The $\mathrm{pH}$ for all depths was acidic and did not show any significant seasonal change (Salinas Villafane et al., 2012). However, the pH of the upper horizons (median value of 3.57 at GL-15 cm and 3.40 at GL-45 cm) decreased significantly when compared to the deeper horizons (median value of 3.18 at GL-70 $\mathrm{cm}$ and 3.04 at GL-95 cm). This behavior can be related to the results obtained in the column experiments by considering the changes in the bedrock thicknesses. The conditions remained oxic at all depths, increasing slightly with depth. These results agreed with those obtained in the columns and confirm highly oxidizing conditions for both column and field systems through the experimental period. The EC values of the shallower horizons $(0.37 \pm 0.25$ $\mathrm{mS} / \mathrm{cm}$ at GL-15 $\mathrm{cm}$ and $0.36 \pm 0.22 \mathrm{mS} / \mathrm{cm}$ at GL- $45 \mathrm{~cm}$ ) were significantly lower than those obtained in the deeper horizons $(0.52 \pm 0.0 .51 \mathrm{mS} / \mathrm{cm}$ at GL-70 $\mathrm{cm}$ and $0.70 \pm 0.46 \mathrm{mS} / \mathrm{cm}$ at GL-95 $\mathrm{cm})$, which suggest an increase of EC with depth, similar to the trend found in column experiments. Here the results are expressed as (average \pm standard deviation)

The concentrations of potentially toxic metals in the porewater for all depths are given in Table 5. The results fluctuated dramatically over the sampling campaigns, as shown by the standard deviations in the table, and did not show a clear trend with respect to depth (Salinas Villafane et al., 2012). On average, $\mathrm{Cu}$ and $\mathrm{Zn}$ concentrations were slightly higher in the deepest porous cups $(2.48 \mathrm{mg} / \mathrm{L}$ of $\mathrm{Cu}$ and $1.25 \mathrm{mg} / \mathrm{L}$ of $\mathrm{Zn}$ ), while $\mathrm{Pb}$ concentration did not change greatly $(4.08 \mathrm{mg} / \mathrm{L}$ at GL-15 cm, $4.02 \mathrm{mg} / \mathrm{L}$ at GL- $95 \mathrm{~cm})$.

\section{Discussion}

\subsection{Acidity of weathered rocks and load of potentially toxic metals}

As demonstrated by the results obtained in the batch and column experiments, as well as the field observations, weathering of the rocks decreased the $\mathrm{pH}$ which appeared to be a long lasting process. Considering the presence of the XRD ray peak of pyrite as a trace mineral and the lower $\mathrm{S}$ content found in the weathered rocks ( 0.77 wt. $\%$ of $\mathrm{K}_{1}, 0.48$ wt. $\%$ of $\mathrm{K}_{2}$, and $0.61 \mathrm{wt} . \%$ of $\mathrm{K}_{3}$ ) compared with the fresh rock sample $\left(\mathrm{K}_{4}\right)$ with pyrite clearly detected by the XRD and a $\mathrm{S}$ content of $1.0 \mathrm{wt} . \%$, and considering the oxidizing conditions, the surface rocks have suffered major mineralogical transformations due to weathering processes, and most of the parent sulfide minerals have been transformed to more labile secondary minerals such as oxides, hydroxides, sulfates and exchangeable phases, which may lead to acidity, in some cases lasting for decades or centuries (Younger, 1997). This is supported by the initial results of the column experiments for all major ions and potentially toxic metals, except for $\mathrm{Pb}$, showing higher concentrations in the first few weeks of the experiments due to the easy dissolution of these labile forms.

Partitioning coefficient values $\left(\log \mathrm{K}_{\mathrm{d}}\right)$ for $\mathrm{Cu}, \mathrm{Pb}$ and $\mathrm{Zn}$ were 2.32, 1.11 and 2.94, respectively. The results indicate that greater relative proportions of $\mathrm{Pb}$ would leach from the rocks, followed by $\mathrm{Cu}$ and $\mathrm{Zn}$. The $\log \mathrm{K}_{\mathrm{d}}$ values obtained here are within the range found in the literature for soil/water systems that are 0.1-3.6 for $\mathrm{Cu}, 0.7-5.0$ for $\mathrm{Pb}$, and (-1.0)-5.0 for Zn (Allison and Allison, 2005).

Although the potentially toxic metal contents of the rocks were within the range found in soil and crustal abundance, concentrations in the filtrates of suspensions, leachates from columns, and porewaters were over the drinking water standards for Japan. According to the Soil Contamination Countermeasures Law of Japan, enforced in February of 2003, Pb, designated as a hazardous substance, has an environment 
standard of $\leq 0.01 \mathrm{mg} / \mathrm{L}$ in the leachate. The $\mathrm{Pb}$ concentration of all samples far exceeded the standard.

\subsection{Potentially toxic metal leaching and mineral equilibria}

By comparing the average concentrations from the column and field experiments, shown in Figure 6, it is noticeable that the results for $\mathrm{Cu}, \mathrm{Pb}$ and $\mathrm{Zn}$ were within an order of magnitude. However, there were differences in concentrations between the experiments. These could be attributed to factors such as difference in particle size (Schaider et al., 2007), hydraulic conductivity, and heterogeneity of the weathered rock layer as well as water availability. Also, as predicted by the partition coefficients in the previous section, $\mathrm{Pb}$ concentrations in leaches were the highest, followed by $\mathrm{Zn}$ and $\mathrm{Cu}$. In the upper part of the field site, variations in concentrations were much greater than those at the bottom, which is attributed to more significant surface weathering that transforms the metals to relatively more mobile forms, while at the bottom variations in concentrations were smaller. On the other hand, in column experiments the maximum values in the figure correspond to the results obtained in the first few weeks, while the minimum values were those obtained in the last few weeks.

The main mechanisms for the release of toxic metals are likely to be the following: easy dissolution of more labile forms and the oxidation of the remaining sulfide minerals in the rocks. The easy dissolution of the more labile phases formed during the weathering process over the last decades at the site, which may include the exchangeable fraction, sulfates and/or hydroxides, is observed at the beginning of the column experiments when high concentrations of major ions and potentially toxic metals were found. These minerals dissolve very rapidly when they are flushed with water (Younger et al., 2002). On the other hand, oxidation of the remaining sulfide minerals is expected to continue until they are depleted from the rocks. In Figure 7 concentrations of $\mathrm{Cu}, \mathrm{Pb}$ and $\mathrm{Zn}$ are plotted against $\mathrm{SO}_{4}{ }^{2-}$ for the column experiments and field site. High positive correlations were found for $\mathrm{Cu}$ and $\mathrm{Zn}$ with respect to $\mathrm{SO}_{4}{ }^{2-}$, in particular for column experiments where crushed rocks provided fresh surfaces for oxidation, which suggest an ongoing oxidation of the remaining sulfide minerals. The plots of field observations do not correlate as well as the plots for column experiments, indicating that there are other mechanisms (e.g. dissolution of oxides, hydroxides, and other secondary minerals) that may be affecting the relationship. However, no correlation was found between $\mathrm{Pb}$ and $\mathrm{SO}_{4}{ }^{2-}$ concentrations for both column and field data. This suggests that after the oxidation of the sulfide minerals, some secondary minerals are been formed and restrict the solubility of $\mathrm{Pb}$. From Table 6, anglesite $\left(\mathrm{PbSO}_{4}\right)$ appears to be the solid phase controlling the solubility of $\mathrm{Pb}$ since the SIs calculated for the samples are positive or very close to zero, which implies that the mineral is precipitating in the system. Samples selected for evaluation in Table 6 were chosen as representative ones by considering the depth and time of experiments.

\subsection{Bedrock height effect}

Concentrations of $\mathrm{Cu}$ and $\mathrm{Zn}$ in the shallower horizons were generally lower than those found in the deeper horizons in both column and field experiments over the study period. This suggests that the concentration increase can be related to the length of flow path through the weathered rock layer. However, $\mathrm{Pb}$ concentrations did not change with increasing bedrock height in both column and field systems. Figure 8 shows the relationship between the activities of potentially toxic metals and $\mathrm{pH}$, and sulfate activity. Solubility products of some $\mathrm{Cu}, \mathrm{Zn}$ and $\mathrm{Pb}$ secondary minerals are also shown. As shown in this figure, there is no evidence that secondary minerals of $\mathrm{Cu}$ and $\mathrm{Zn}$ were formed which could be affecting their solubility in water, which is in line with their increasing concentration with the flow path length. However, $\mathrm{Pb}$ plots on the solubility line for anglesite $\left(\mathrm{PbSO}_{4}\right)$, suggesting that this mineral, which is known to precipitate at low $\mathrm{pH}$ (Nordstrom, 2011), is limiting the solubility of $\mathrm{Pb}$ in the system.

As a reference, metal concentrations in groundwater samples (GL-35 m) obtained from a borehole located near the field observation area, were analyzed. Samples were collected during five sampling 
campaigns between December of 2009 and November of 2010. The results obtained were as follows: $16.2 \pm 2.17 \mathrm{mg} / \mathrm{L}$ for $\mathrm{Cu}, 1.82 \pm 0.36 \mathrm{mg} / \mathrm{L}$ for $\mathrm{Pb}$, and $16.4 \pm 0.89 \mathrm{mg} / \mathrm{L}$ for $\mathrm{Zn}$. This supports the assumption that $\mathrm{Cu}$ and $\mathrm{Zn}$ concentrations increase with depth while $\mathrm{Pb}$ concentration is limited by the precipitation of $\mathrm{PbSO}_{4}$. Despite this general observation, there may be some other kinetic constraints on mineral equilibrium and adsorption/desorption processes that affect the metal concentrations in groundwater.

\section{Conclusions}

Chemical characterization of leachates obtained from column experiments and porewater obtained from field observations at a closed mine site were performed to understand the leaching behavior of $\mathrm{Cu}, \mathrm{Pb}$ and $\mathrm{Zn}$ from weathered rocks. The $\mathrm{pH}$ was acidic and did not fluctuate significantly over the course of the columns experiments (75 weeks) and field observations (from November 2009 to June 2011). Copper and $\mathrm{Zn}$ concentrations increased with depth while $\mathrm{Pb}$ concentrations remained almost unchanged, which suggests that other minerals may restrict its solubility. By geochemical calculations, it was found that anglesite may be the phase controlling the $\mathrm{Pb}$ leaching. To support this observation, groundwater samples obtained at the site were analyzed to compare the $\mathrm{Cu}, \mathrm{Pb}$ and $\mathrm{Zn}$ concentrations. The results of $\mathrm{Cu}$ and $\mathrm{Zn}$ concentrations in the groundwater were higher while the $\mathrm{Pb}$ concentration was almost equal to the results of column leachates and porewaters.

The main release mechanisms for the potentially toxic metals seem to be the easy dissolution of more labile species (exchangeable, sulfates and hydroxides) and the oxidation of the remaining sulfide minerals.

Based on these results, at former mine sites the thickness of the weathered rock layer is an important parameter that should be determined to estimate the loads of potentially toxic metals, which must be considered when designing remediation schemes.

\section{Acknowledgements}

This research was partly supported by the Ministry of Economy, Trade and Industry of Japan. 


\section{References}

Akcil, A., Koldas, S., 2006. Acid mine drainage (AMD): Causes, treatment and case studies. J. Cleaner Production, 14, 1139-1145.

Allison, J.D., Allison, T.L., 2005. Partition coefficients for metals in surface water, soil, and waste. US Environmental Protection Agency, EPA/600/R-05/074.

Azapagic, A., 2004. Developing a framework for sustainable development indicators for the mining and minerals industry. J. Cleaner Production 12, 639-662.

Azcue, J.M., Mudroch, A., Rosa, F., Hall, G.E.M., Jackson, T.A., Reynoldson, T., 1995. Trace elements in water, sediments, porewater, and biota polluted by tailings from an abandoned gold mine in British Columbia, Canada. J. Geochem. Explor. 52, 25-34.

Bech, J., Roca, N., Barceló, J., Duran, P., Tume, P., Poschenrieder, C., 2012. Soil and plant contamination by lead mining in Bellmunt, Western Mediterranean Area. J. Geochem. Explor. 113, 94-99.

Camargo, I.M.C., Hiromoto, G., Flues, M., 2007. Heavy metal partition in acid soils contaminated by coal power plant. J. Brazilian Chem. Soc. 18, 831-837.

Dubrovsky, N.M., Cherry, J.A., and Reardon, E.J., 1985. Geochemical evolution of inactive pyritic tailings in the Elliot Lake uranium district. Can. Geotech. J. 22, 110-128.

Emsley, J., 2003. Nature's Building Blocks: An A-Z Guide to the Elements. Oxford University Press, New York.

Hudson-Edwards, K.A., Macklin, M.G., Jamieson, H.E., Brewer, P.A., Coulthard, T.J., Howard, A.J., Turner, J.N., 2003. The impact of tailings dam spills and clean-up operations on sediment and water quality in river systems: the Ríos Agrio-Guadiamar, Aznalcóllar, Spain. Appl. Geochem. 18, 221-239.

Johnson, D.B., Hallberg, K.B., 2005. Acid mine drainage remediation options: A review. Sci. Total Environ. 338, 3-14.

Jung, M.C., Thornton, I., 1997. Environmental contamination and seasonal variation of metals in soils, plants and waters in the paddy fields around a $\mathrm{Pb}-\mathrm{Zn}$ mine in Korea. Sci. Total Environ. 198, 105-121.

Jurjovec, J., Ptacek, C.J., Blowes, D.W., 2002. Acid neutralization mechanisms and metal release in mine tailings: A laboratory column experiment. Geochim. Cosmochim. Acta 66, 1511-1523.

Kabata-Pendias, A., Pendias, H., 2001. Trace Elements in Soils and Plants, $3^{\text {rd }}$ ed. CRC Press, Boca Raton.

Kossoff, D., Hudson-Edwards, K.A., Dubbin, W.E., Alfredsson, M.A., 2011. Incongruent weathering of Cd and $\mathrm{Zn}$ from mine tailings: A column leaching study. Chem. Geol. 281, 52-71.

Lee, S., 2006. Geochemistry and partitioning of trace metals in paddy soils affected by metal mine tailings in Korea. Geoderma, 135, 26-37.

Miller, J. R., 1997. The role of fluvial geomorphic processes in the dispersal of heavy metals from mine sites. J. Geochem. Explor. 58, 101-118.

Miller, J.R., Hudson-Edwards, K.A., Lechler, P.J., Preston, D., Macklin, M.G., 2004. Heavy metal contamination of water, soil and produce within riverine communities of the Rio Pilcomayo basin, Bolivia. Sci. The Total Environ. 320, 189-209.

Mitsubishi Materials Corporation, 2010. Field experiments on improving the quantity and quality of acid mine drainage by controlling surface conditions and groundwater flow at Komaki mine. A government-aided project of advance technology on acid mine drainage treatment.

Nordstrom, D.K., 2011. Hydrogeochemical processes governing the origin, transport and fate of major and trace elements from mine wastes and mineralized rock to surface waters. Appl. Geochem. 26, 1777-1791.

Parkhurst, D.L., Appelo, C.A.J., 1999. User's guide to PHREEQC (Version 2) - A computer program for speciation, batch-reaction, one-dimensional transport, and inverse geochemical calculations. U.S. Geol. Surv. Water-Resour. Invest. Rep. 99-4259.

Ramos Arroyo, Y. R., Siebe, C., 2007. Weathering of sulphide minerals and trace element speciation in 
tailings of various ages in the Guanajuato mining district, Mexico. Catena 71, 497-506

Sahu, K.C., Prusty, B.G., Godgul, G., 1994. Metal contamination due to mining and milling activities at the Zawar zinc mine, Rajasthan, India: 2. Dispersion in floodplain soils of stream. Chem. Geol. 112, 293-307.

Salinas Villafane, O.R., Igarashi, T., Harada, S., Kurosawa, M., Takase, T., 2012. Effect of different soil layers on porewater to remediate acidic surface environment at a close mine site. Environ. Monitor. Assess. doi:10.1016/j.geoderma.2010.11.008, in press.

Salinas Villafane, O.R., Kawahara, T., Igarashi, T., 2009. Remediation of acidic surface soil at a closed mine. Proc. $3^{\text {rd }}$ Internat. Workshop and Conf. Earth Resources Technology, Sapporo, Japan, CD-ROM.

Schaider, L.A., Senn, D.B., Brabander, D.J., McCarthy, K.D., Shine, J.P., 2007. Characterization of zinc, lead, and cadmiun in mine waste: Implications for transport, exposure, and bioavailability. Environ. Sci. Technol. 41, 4164-4171.

Sposito, G., 1989. The Chemistry of Soils. Oxford University Press, New York.

Younger, P.L., 1997. The longevity of minewater pollution: A basis for decision-making. Sci. Total Environ. 194/195, 457- 466.

Younger, P.L., Banward, S.A., Hedin, R.S., 2002. Mine Water: Hydrology, Pollution, Remediation. Kluver Academic Publishers, London. 


\section{Figure captions}

Fig. 1 General view of the former mine site with location of sampling areas and field observation sites

Fig. 2 Schematic of the columns used

Fig. 3 Porous cups setup at the site: (a) a vertical section and (b) a plan view

Fig. $4 \mathrm{pH}$ (a), ORP (b), and EC (c) changes with time for column leachate

Fig. 5 Changes in potentially toxic metal and major ion concentrations with time for column leachate; (a) $\mathrm{Cu}$, (b) $\mathrm{Fe}$, (c) $\mathrm{Pb}$, (d) $\mathrm{Zn}$, (e) $\mathrm{Ca}^{2+}$, (f) $\mathrm{SO}_{4}^{2-}$, (g) $\mathrm{Mg}^{2+}$, and (h) $\mathrm{Cl}^{-}$

Fig. 6 Evolution of potentially toxic metal concentrations with depth for column and field experiments (lines at the extremes represent the minimum and maximum values while marks in between represent the means); (a) $\mathrm{Cu}$, (b) $\mathrm{Pb}$, and (c) $\mathrm{Zn}$

Fig. $7 \mathrm{Cu}^{2+}$ (a), $\mathrm{Pb}^{2+}$ (b), and $\mathrm{Zn}^{2+}$ (c) concentrations as a function of $\mathrm{SO}_{4}{ }^{2-}$ concentrations for column experiments and field observations

Fig. 8 Comparison of calculated activities of $\mathrm{Cu}, \mathrm{Pb}$, and $\mathrm{Zn}$ for column experiments and field observations with theoretical straight lines expressing potential solubility controlling liquid-phase concentrations 


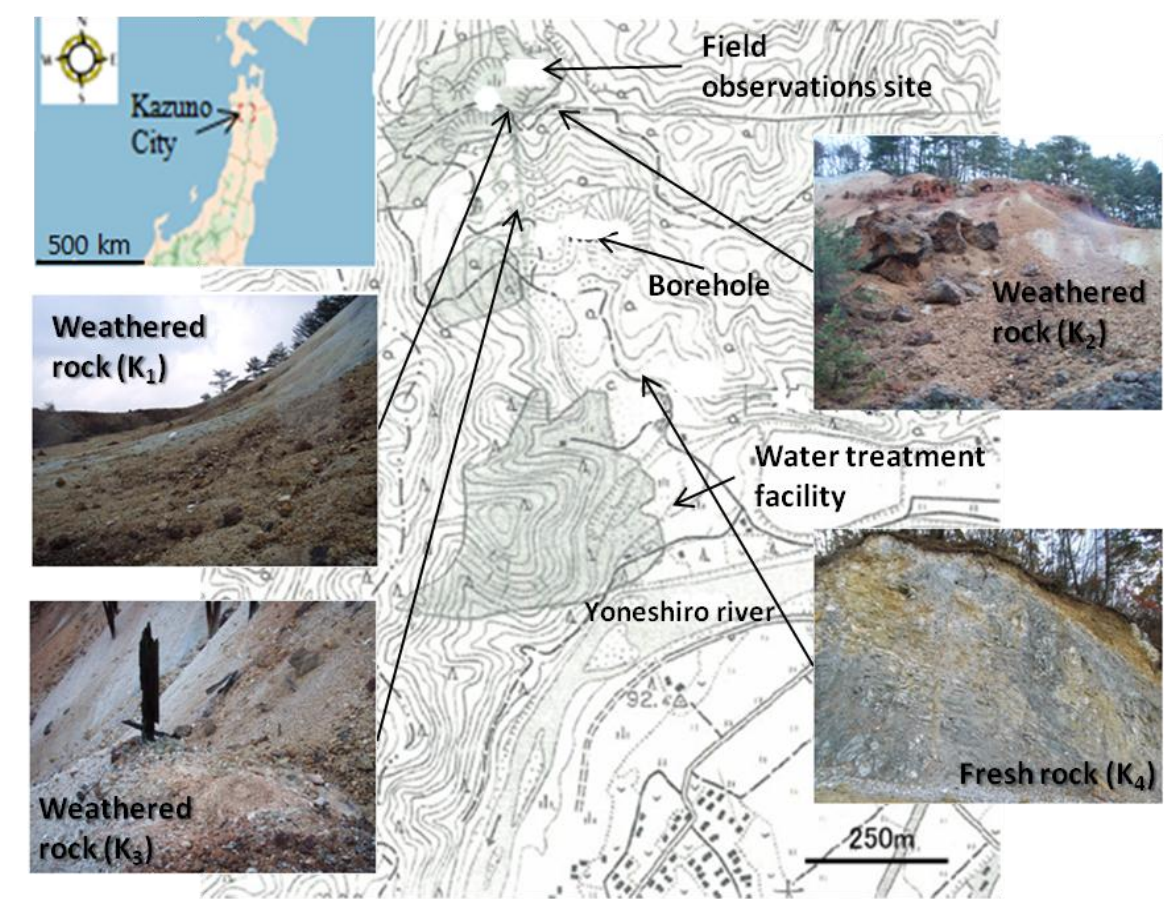

Fig. 1 


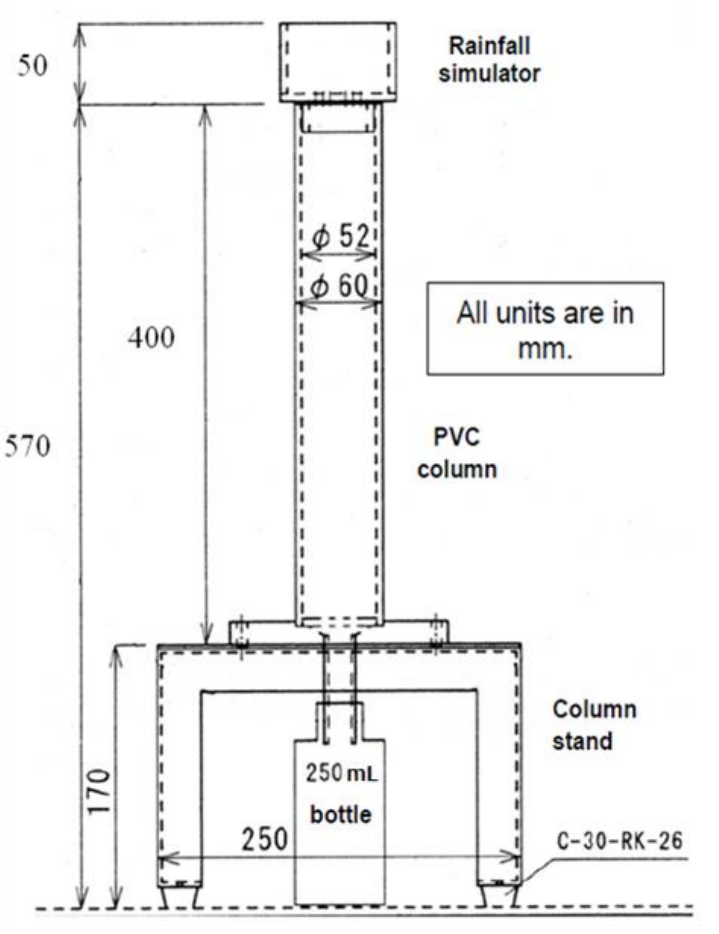

Fig. 2

pg. 3 

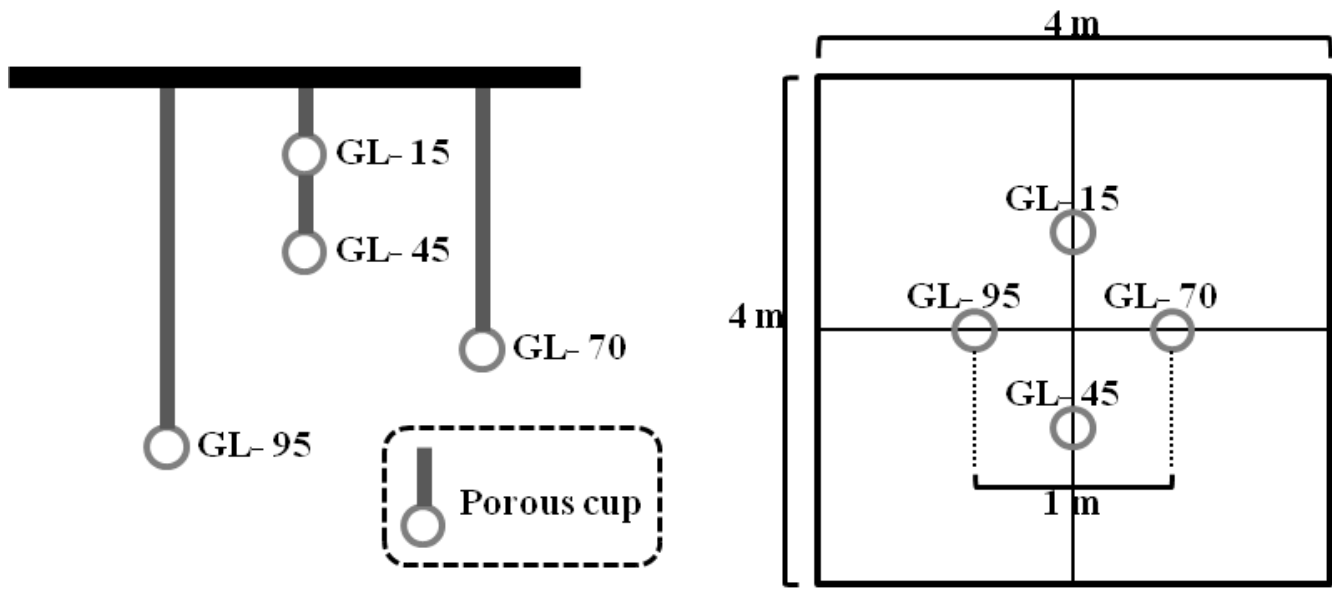

Fig. 3

pg. 4 
(a)

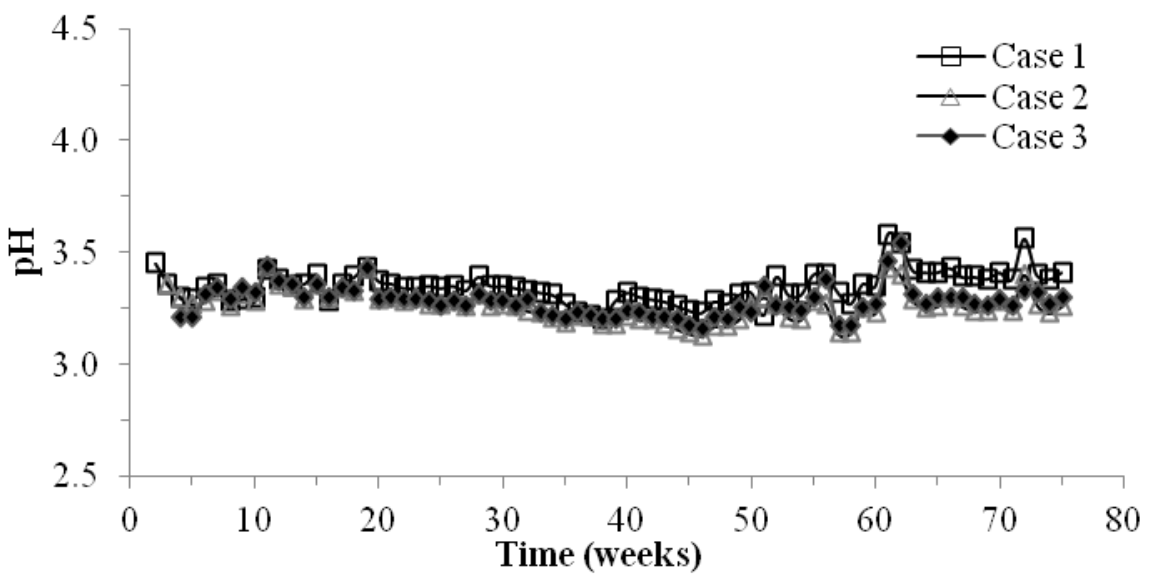

(b)
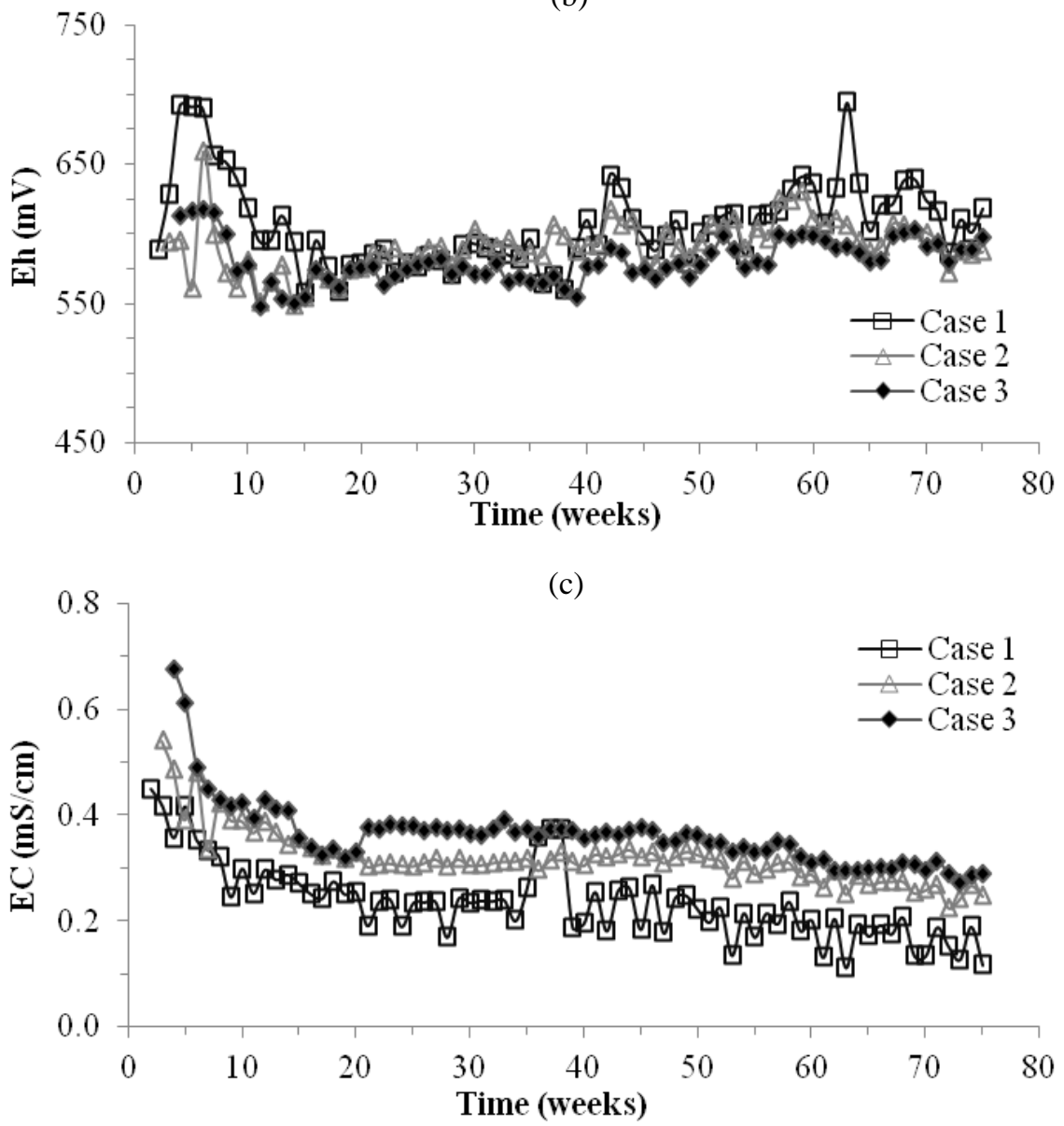

Fig. 4

pg. 5 
(a)

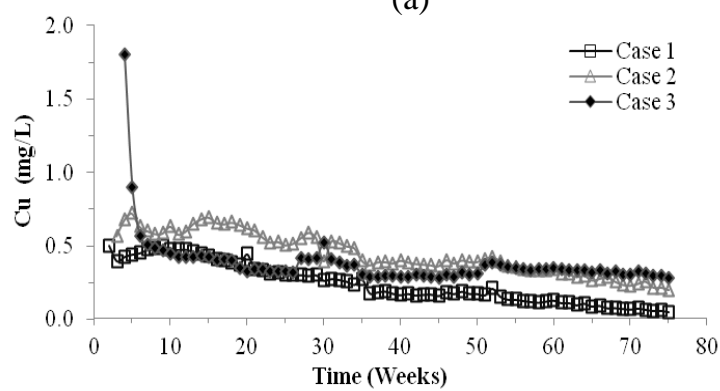

(c)

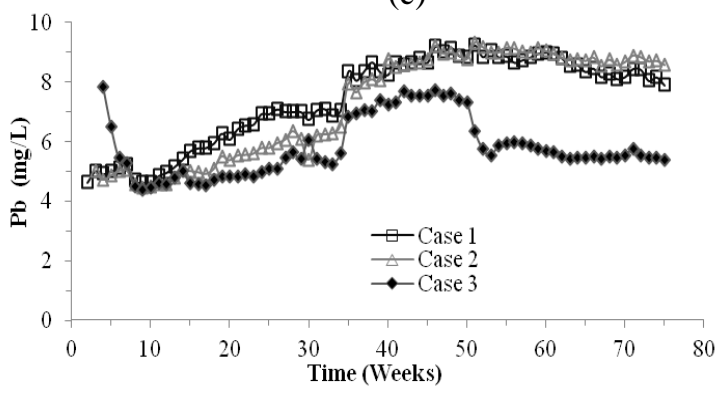

(e)

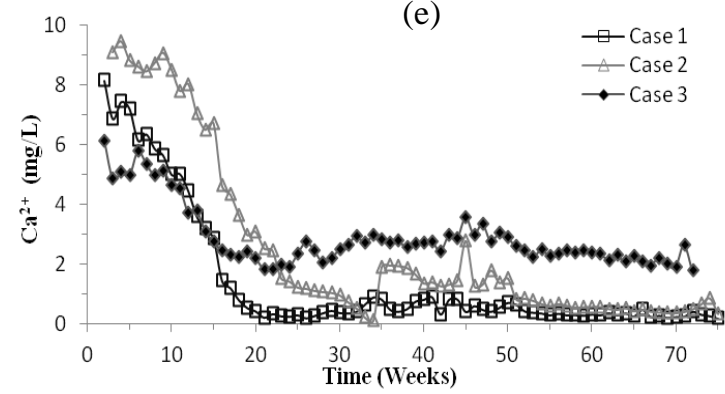

(g)

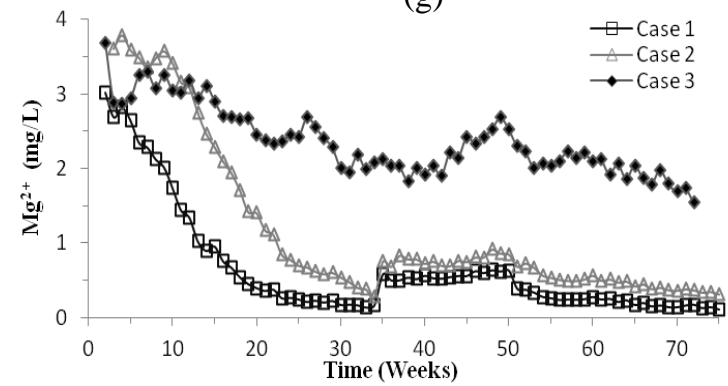

(b)

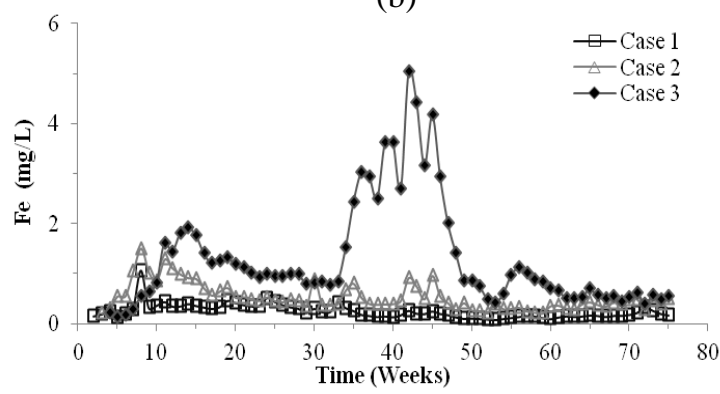

(d)

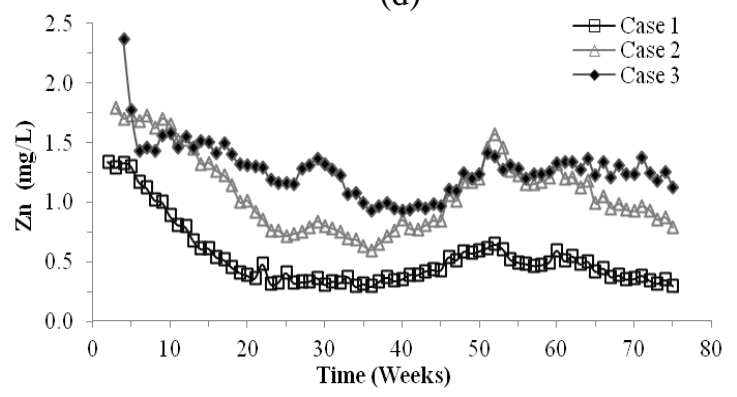

(f)

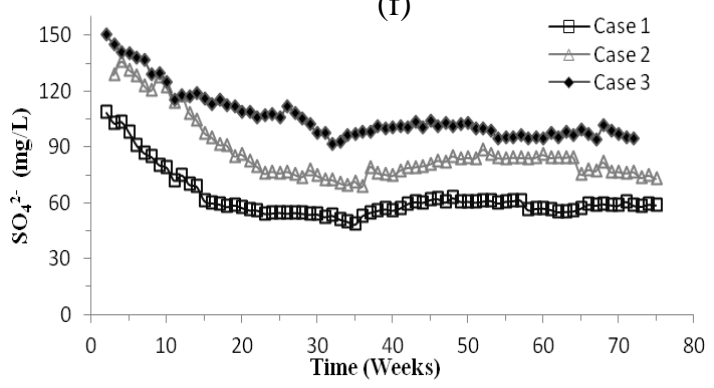

(h)

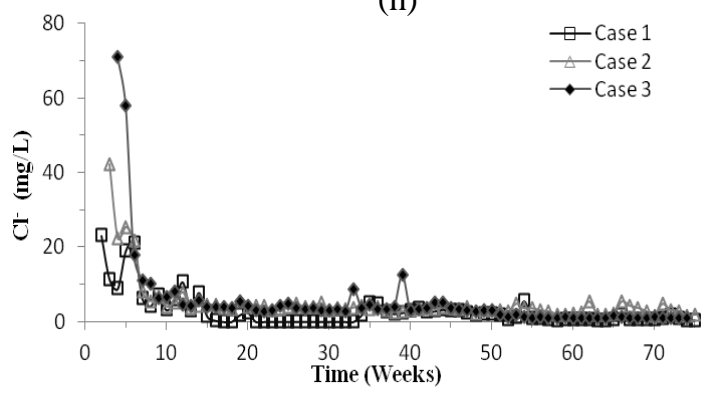

Fig. 5 
(a)

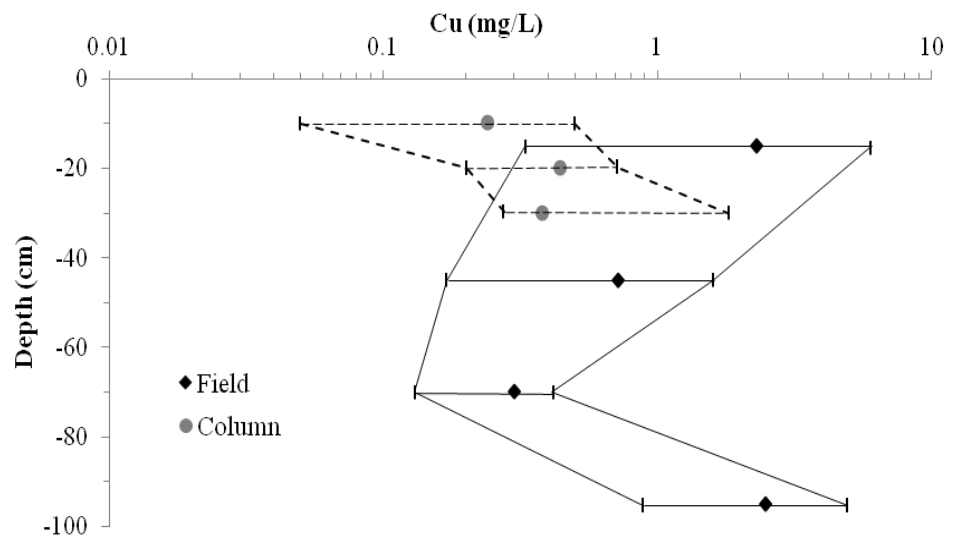

(b)

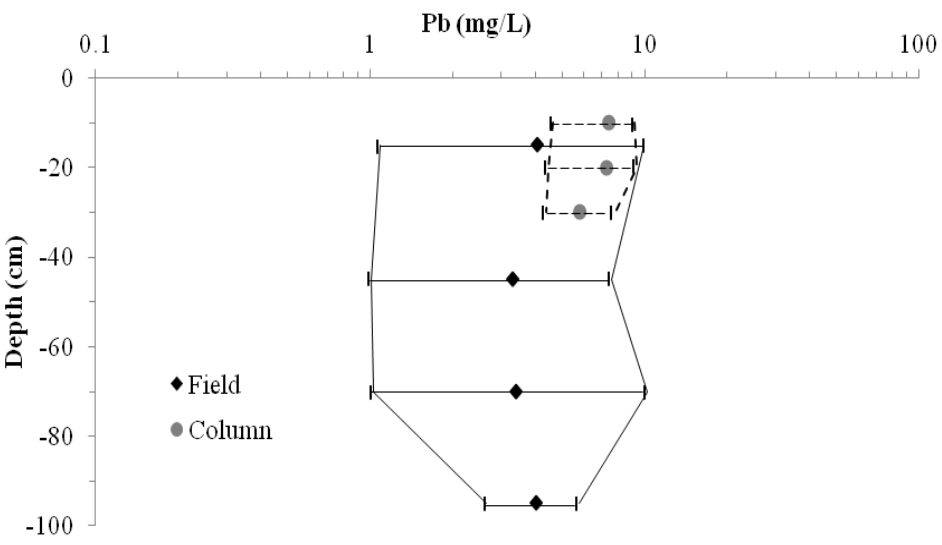

(c)

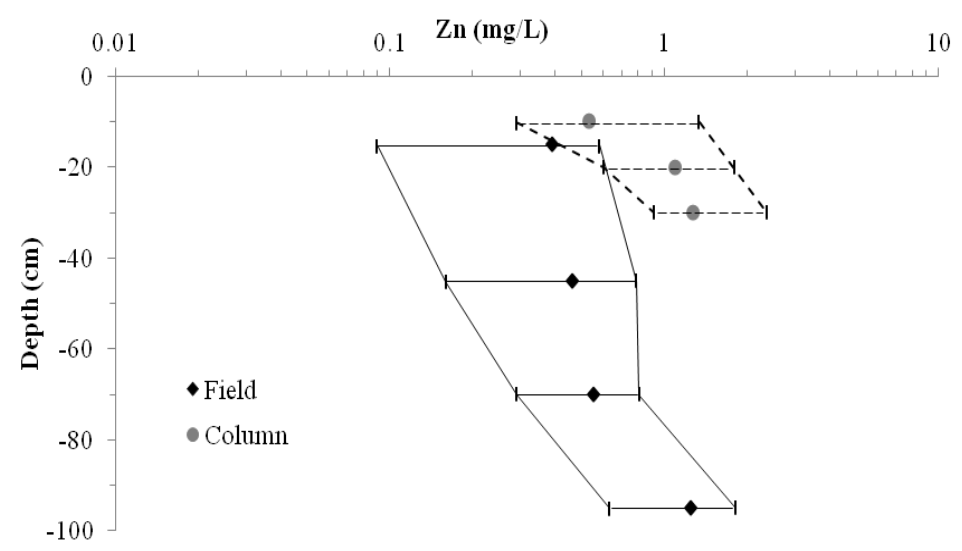

Fig. 6

pg. 7 
(a)

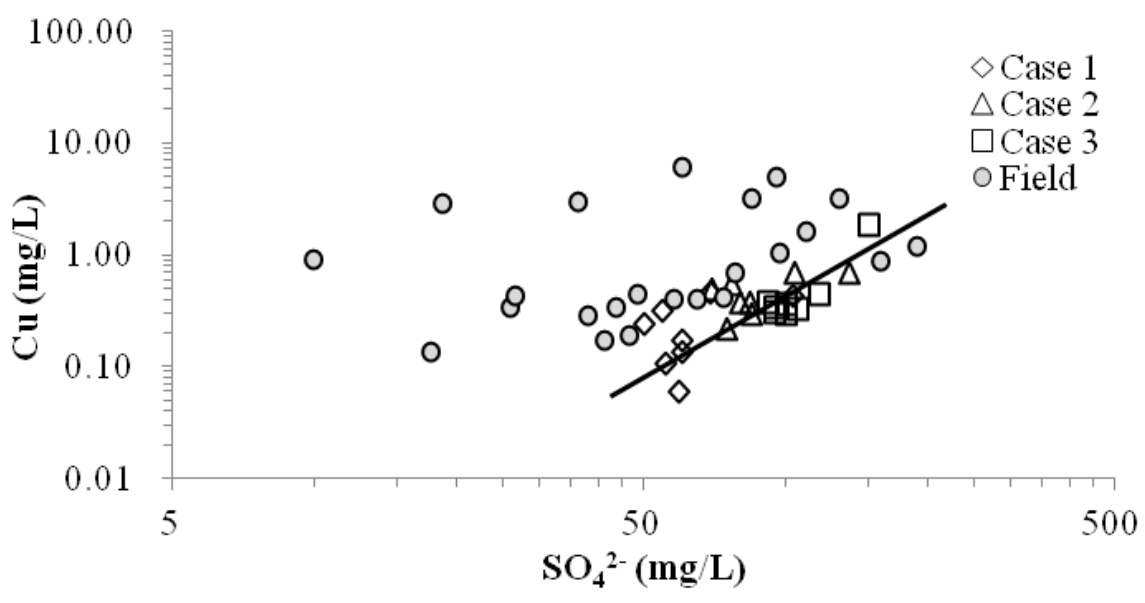

(b)

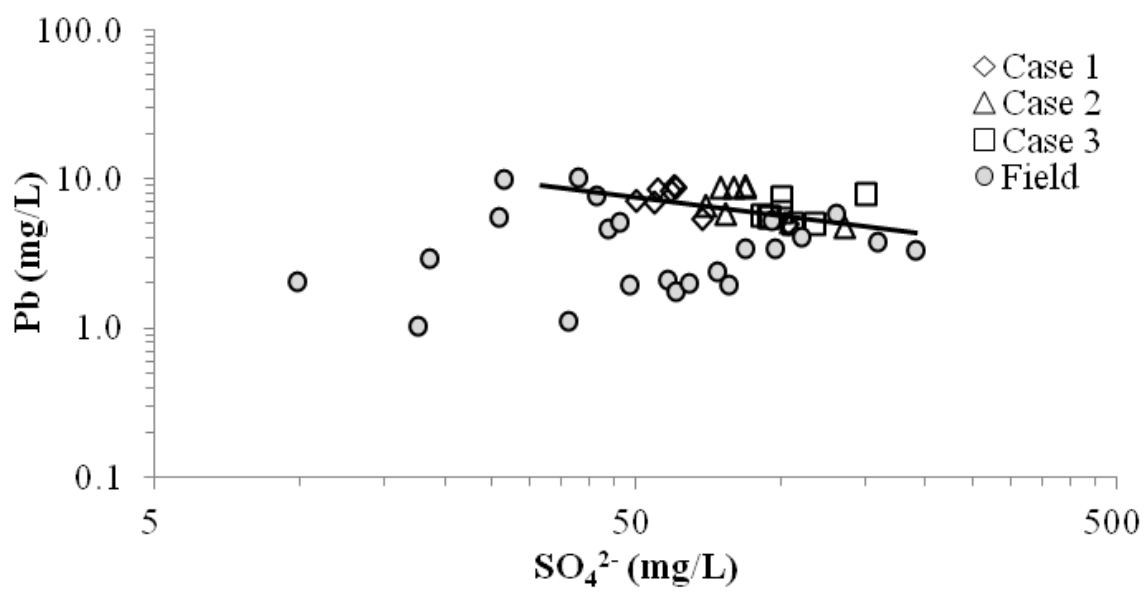

(c)

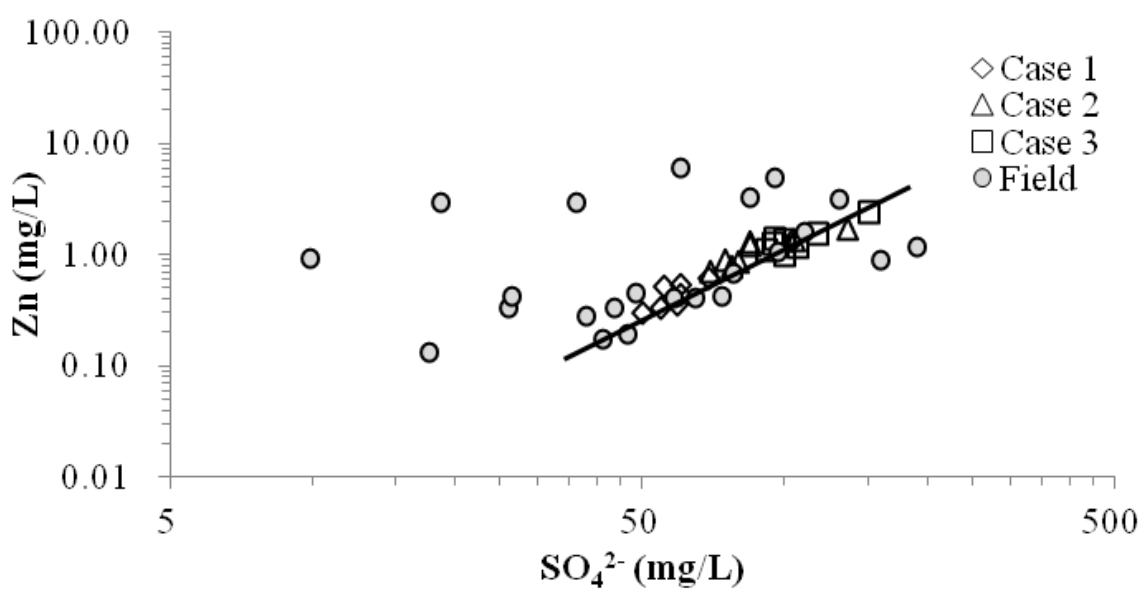

Fig. 7

pg. 8 

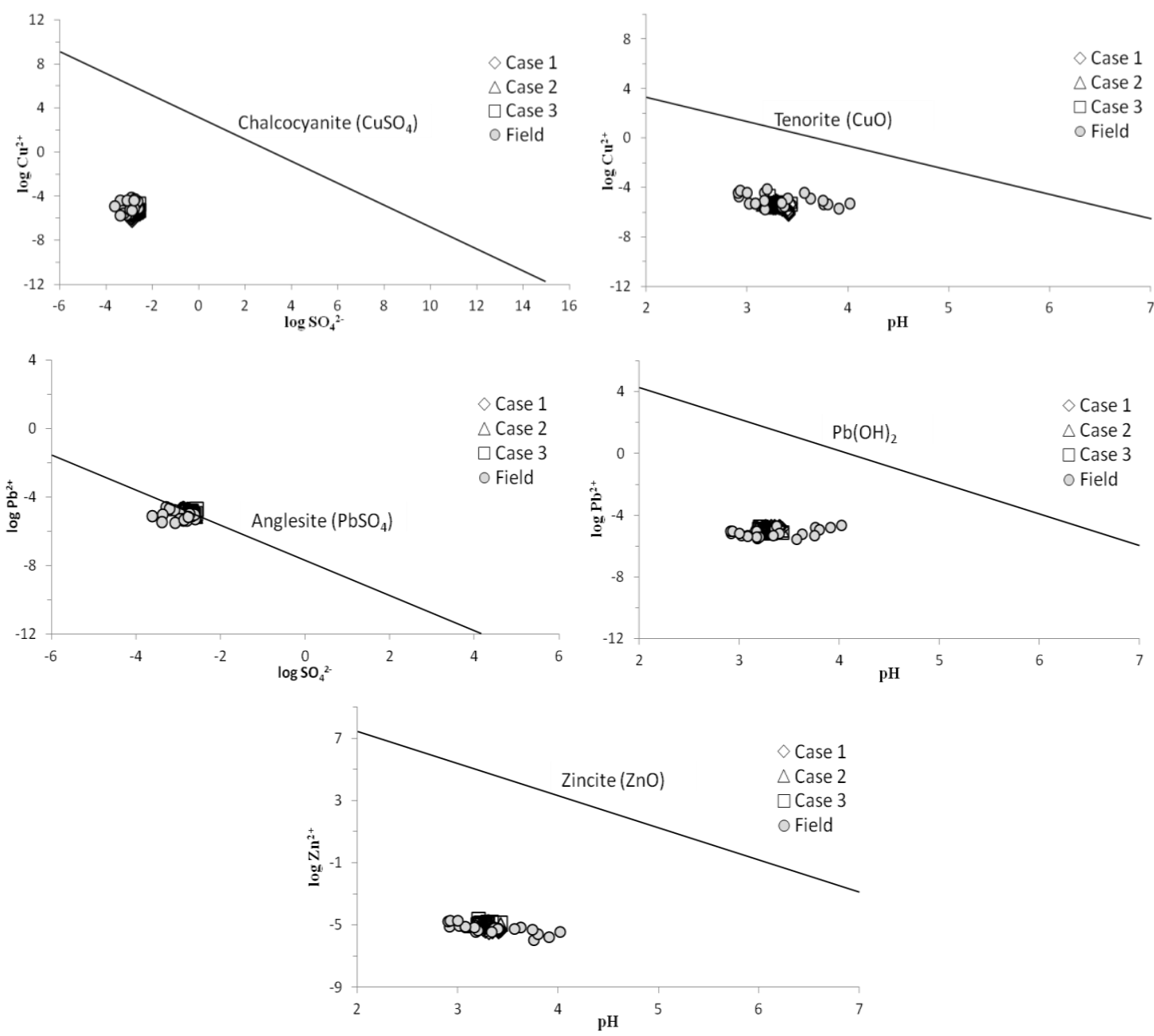

Fig. 8

pg. 9 
Table 1 Chemical compositions of rock samples collected

\begin{tabular}{|c|c|c|c|c|c|c|c|c|c|c|c|c|c|c|}
\hline Sample & $\begin{array}{c}\mathrm{SiO}_{2} \\
\text { (wt.\%) }\end{array}$ & $\begin{array}{c}\mathrm{TiO}_{2} \\
\text { (wt.\%) }\end{array}$ & $\begin{array}{l}\mathrm{Al}_{2} \mathrm{O}_{3} \\
\text { (wt.\%) }\end{array}$ & $\begin{array}{l}\mathrm{Fe}_{2} \mathrm{O}_{3} \\
\text { (wt.\%) }\end{array}$ & $\begin{array}{c}\mathrm{MnO} \\
(\mathrm{wt} \%)\end{array}$ & $\begin{array}{c}\mathrm{MgO} \\
\text { (wt.\%) }\end{array}$ & $\begin{array}{c}\mathrm{CaO} \\
(\mathrm{wt} \%)\end{array}$ & $\begin{array}{l}\mathrm{Na}_{2} \mathrm{O} \\
\text { (wt.\%) }\end{array}$ & $\begin{array}{c}\mathrm{K}_{2} \mathrm{O} \\
(\mathrm{wt} . \% \text { ) }\end{array}$ & $\begin{array}{c}\mathrm{P}_{2} \mathrm{O}_{5} \\
(\mathrm{wt} . \%)\end{array}$ & $\begin{array}{c}\mathrm{S} \\
\text { (wt.\%) }\end{array}$ & $\begin{array}{c}\mathrm{Cu} \\
(\mathrm{ppm})\end{array}$ & $\begin{array}{c}\mathrm{Pb} \\
(\mathrm{ppm})\end{array}$ & $\begin{array}{c}\mathrm{Zn} \\
(\mathrm{ppm})\end{array}$ \\
\hline $\mathrm{K}_{1}$ & 63.2 & 0.72 & 11.8 & 6.52 & 0.03 & 3.73 & 2.58 & 0.24 & 2.39 & 0.09 & 0.77 & 34.0 & 15.5 & 95.0 \\
\hline $\mathrm{K}_{2}$ & 69.0 & 0.69 & 9.29 & 5.82 & 0.03 & 2.78 & 2.91 & 1.00 & 1.86 & 0.08 & 0.48 & 39.8 & 10.0 & 81.8 \\
\hline $\mathrm{K}_{3}$ & 70.3 & 0.65 & 8.94 & 5.13 & 0.05 & 2.62 & 2.55 & 0.70 & 2.33 & 0.02 & 0.61 & 37.2 & 14.7 & 90.4 \\
\hline $\mathrm{K}_{4}$ & 72.7 & 0.13 & 12.5 & 2.54 & 0.01 & 1.31 & 0.01 & 0.19 & 3.96 & 0.03 & 1.00 & 98.0 & 23.0 & 31.0 \\
\hline
\end{tabular}

pg. 1 
Table 2 Mineral constituents of the rock samples collected

\begin{tabular}{ccc}
\hline Sample name & Identified mineral & Degree of weathering \\
\hline $\mathrm{K}_{1}$ & Quartz, (pyrite) & Weathered \\
$\mathrm{K}_{2}$ & Quartz, feldspar, (barite), (pyrite) & Weathered \\
$\mathrm{K}_{3}$ & Quartz, (pyrite) & Weathered \\
$\mathrm{K}_{4}$ & Quartz, pyrite & Fresh \\
\hline
\end{tabular}

( ): Minor constituents

pg. 2 
Table 3 Chemical compositions of leachates from rock samples obtained in the batch experiments (unit: $\mathrm{mg} / \mathrm{L}$, except for $\mathrm{pH})$

\begin{tabular}{ccccccccc}
\hline Sample & $\mathrm{pH}$ & $\mathrm{Ca}$ & $\mathrm{Mg}$ & $\mathrm{SO}_{4}{ }^{2-}$ & $\mathrm{Cu}$ & $\mathrm{Fe}$ & $\mathrm{Pb}$ & $\mathrm{Zn}$ \\
\hline $\mathrm{K}_{1}$ & 3.02 & 0.79 & 0.28 & 65.1 & 0.33 & 1.40 & 0.19 & 0.03 \\
$\mathrm{~K}_{2}$ & 2.96 & 1.16 & 0.48 & 37.0 & 0.17 & 0.24 & 4.20 & 0.26 \\
$\mathrm{~K}_{3}$ & 3.77 & 0.78 & 0.11 & 38.1 & 0.11 & 0.03 & 0.50 & 0.03 \\
$\mathrm{~K}_{4}$ & 4.52 & 0.08 & 0.12 & 12.0 & 0.39 & 0.59 & 0.01 & 0.02 \\
\hline
\end{tabular}

pg. 3 
Table $4 \mathrm{pH}$, ORP and EC of porewater samples collected from the field

\begin{tabular}{lcccc}
\hline \multicolumn{5}{c}{$\mathrm{pH}$} \\
\hline GL* $(\mathrm{cm})$ & -15 & -45 & -70 & -95 \\
Min & 2.90 & 2.92 & 3.02 & 2.91 \\
Max & 4.40 & 3.91 & 3.47 & 3.75 \\
Median & 3.57 & 3.40 & 3.18 & 3.04 \\
\hline \multicolumn{5}{c}{ Eh $(\mathrm{mV})$} \\
\hline GL* $(\mathrm{cm})$ & -15 & -45 & -70 & -95 \\
Min & 561 & 533 & 592 & 551 \\
Max & 667 & 694 & 702 & 720 \\
Mean & 627 & 627 & 651 & 631 \\
Median & 660 & 670 & 628 & 629 \\
SD & 50 & 67 & 44 & 70 \\
\hline \multicolumn{2}{c}{ EC $(\mathrm{mS} / \mathrm{cm})$} & & \\
\hline GL* $(\mathrm{cm})$ & -15 & -45 & -70 & -95 \\
Min & 0.13 & 0.16 & 0.19 & 0.28 \\
Max & 0.82 & 0.81 & 1.65 & 1.58 \\
Mean & 0.37 & 0.36 & 0.52 & 0.70 \\
Median & 0.28 & 0.29 & 0.38 & 0.60 \\
SD & 0.25 & 0.22 & 0.51 & 0.46 \\
\hline
\end{tabular}

Note: Total number of samples collected is 7 over a period of 20 months (from Nov-2009 to Jun-2011),

GL*: Ground level

pg. 4 
Table 5 Potentially toxic metal concentrations in porewater samples

\begin{tabular}{|c|c|c|c|c|}
\hline \multicolumn{5}{|c|}{$\mathrm{Cu}(\mathrm{mg} / \mathrm{L})$} \\
\hline $\mathrm{GL}(\mathrm{cm})$ & -15 & -45 & -70 & -95 \\
\hline Min & 0.33 & 0.17 & 0.13 & 0.87 \\
\hline $\operatorname{Max}$ & 6.01 & 1.59 & 0.41 & 4.85 \\
\hline Mean & 2.29 & 0.72 & 0.30 & 2.48 \\
\hline Median & 2.02 & 0.68 & 0.28 & 2.46 \\
\hline $\mathrm{SD}$ & 2.15 & 0.48 & 0.11 & 1.53 \\
\hline \multicolumn{5}{|c|}{$\mathrm{Pb}(\mathrm{mg} / \mathrm{L})$} \\
\hline $\mathrm{GL}(\mathrm{cm})$ & -15 & -45 & -70 & -95 \\
\hline Min & 1.09 & 1.01 & 1.03 & 2.64 \\
\hline Max & 9.98 & 7.56 & 10.2 & 5.76 \\
\hline Mean & 4.08 & 3.31 & 3.40 & 4.02 \\
\hline Median & 3.09 & 2.01 & 2.07 & 3.56 \\
\hline $\mathrm{SD}$ & 3.26 & 2.28 & 3.28 & 1.21 \\
\hline \multicolumn{5}{|c|}{$\mathrm{Zn}(\mathrm{mg} / \mathrm{L})$} \\
\hline $\mathrm{GL}(\mathrm{cm})$ & -15 & -45 & -70 & -95 \\
\hline Min & 0.09 & 0.16 & 0.29 & 0.63 \\
\hline Max & 0.58 & 0.79 & 0.81 & 1.83 \\
\hline Mean & 0.39 & 0.46 & 0.55 & 1.25 \\
\hline Median & 0.41 & 0.43 & 0.65 & 1.31 \\
\hline SD & 0.16 & 0.24 & 0.22 & 0.56 \\
\hline
\end{tabular}

Note: Total number of samples collected is 7 over a period of 20 months (from Nov-2009 to Jun-2011),

GL*: Ground level

pg. 5 


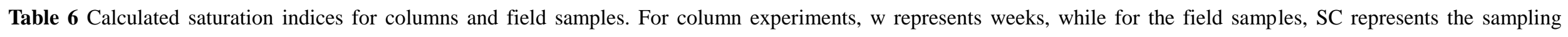
campaign.

\begin{tabular}{|c|c|c|c|c|c|c|c|c|c|c|}
\hline \multirow{3}{*}{ Parameter } & \multicolumn{2}{|c|}{ Case 1} & \multicolumn{2}{|c|}{ Case 2} & \multicolumn{2}{|c|}{ Case 3} & \multicolumn{4}{|c|}{ Field } \\
\hline & w 14 & w 50 & w 14 & w 50 & w 14 & w 50 & 1st SC & 3rd SC & 4th SC & 6th SC \\
\hline & W 14 & w & W 14 & w 30 & W 14 & w 50 & GL-15 & GL-45 & GL-70 & GL-95 \\
\hline $\mathrm{pH}$ (measured) & 3.36 & 3.32 & 3.29 & 3.26 & 3.30 & 3.23 & 3.76 & 3.40 & 3.02 & 3.00 \\
\hline pe (calculated from Eh) & 10.0 & 10.2 & 9.28 & 10.1 & 9.3 & 9.75 & 9.90 & 11.3 & 10.6 & 11.9 \\
\hline \multicolumn{11}{|l|}{ Saturation indices } \\
\hline Goethite (FeOOH) & 1.97 & 1.51 & 1.38 & 1.53 & 1.74 & 1.64 & 2.15 & 3.01 & 1.17 & 2.51 \\
\hline Gypsum $\left(\mathrm{CaSO}_{4} \cdot 2 \mathrm{H}_{2} \mathrm{O}\right)$ & -2.53 & -3.22 & -2.12 & -2.80 & -2.34 & -2.41 & -3.31 & -3.61 & -3.26 & -2.49 \\
\hline Lepidocrocite (FeOOH) & 0.95 & 0.48 & 0.36 & 0.51 & 0.71 & 0.61 & 1.12 & 1.98 & 0.15 & 1.48 \\
\hline Hematite, alpha $\left(\mathrm{Fe}_{2} \mathrm{O}_{3}\right)$ & 3.45 & 2.53 & 2.27 & 2.57 & 2.98 & 2.79 & 3.80 & 5.53 & 1.85 & 4.52 \\
\hline $\begin{array}{l}\text { Maghemite disordered } \\
\qquad\left(\mathrm{Fe}_{2} \mathrm{O}_{3}\right)\end{array}$ & 0.08 & -0.84 & -1.10 & -0.80 & -0.39 & -0.58 & 0.43 & 2.16 & -1.52 & 1.15 \\
\hline $\mathrm{Fe}(\mathrm{OH})_{3(\mathrm{am})}$ & -2.19 & -2.66 & -2.78 & -2.63 & -2.43 & -2.52 & -2.02 & -1.16 & -2.99 & -1.66 \\
\hline $\mathrm{CuSO}_{4}$ & -10.94 & -11.40 & -10.64 & -10.94 & -10.80 & -11.00 & -11.40 & -11.37 & -11.07 & -10.05 \\
\hline $\mathrm{ZnSO}_{4}$ & -10.99 & -11.04 & -10.52 & -10.62 & -10.43 & -10.57 & -12.14 & -11.87 & -10.94 & -10.50 \\
\hline Anglesite $\left(\mathrm{PbSO}_{4}\right)$ & 0.10 & 0.29 & 0.14 & 0.35 & 0.15 & 0.30 & -0.12 & -0.89 & -0.36 & -0.08 \\
\hline $\mathrm{Pb}(\mathrm{OH})_{2}$ & -6.36 & -6.20 & -6.61 & -6.39 & -6.62 & -6.56 & -5.51 & -6.49 & -7.42 & -7.32 \\
\hline
\end{tabular}

